\title{
Významné historické zmeny fluviálneho systému dolného Váhu a význam mechanizmu avulzií $v$ jeho vývoji
}

\author{
Juraj PROCHÁZKA
}

\begin{abstract}
Significant historic changes of the lower Váh River fluvial system and relevance of avulsions on its development
\end{abstract}

Abstract: According to the most recent studies of the lower Váh River fluvial system, alongside with a lateral shift of the channel due to meandering, first-order avulsions also played a key role in the development of the fluvial system. The most important avulsion that already occurred in historical periods produced more stable lateral channels. To study how this geomorphic phenomenon was manifested we used old maps of different scales (from the 16th century onward), modern topographic maps, orthophoto and references in historical literature. This allows ancient paleochannels of the lower Váh River originated by avulsions to be recognised. A good example is represented by major section of the former Váh mainstream channel, so called "Ship Route" (in Hungarian Hajo út). On the lowermost section of the Váh River (stretch from Neded to Komárno) there is a clear tendency of the river to switch its channel to the southwest, in the opposite direction as it is on the Podunajska pahorkatina Hillland. This tendency is tectonically conditioned and it points to the controlling influence of tectonics as the major causative factor in the development of the pre-regulation lower Váh River system. Importance of this paper is twofold. Firstly, it explores the key role of avulsions in the river dynamics on the Podunajská nižina Lowland, not only in sections with higher energy as predicted previously. Secondly, the study brings original knowledge about Váh River channels, which fell into oblivion, but were also important for the then society.

Keywords: Váh River, avulsion, tectonics, old maps, toponym

\section{Úvod}

Vývoj fluviálneho systému dolného Váhu bol v historických obdobiach ovplyvnený mnohými faktormi (najmä fluktuáciami klímy počas stredovekého klimatického optima a malej doby l'adovej a aktivitami človeka v krajine), a ako dynamický geosystém reagoval na zmeny v povodí rôznymi mechanizmami, viditel'ne napr. zmenou typu pôdorysnej vzorky a parametrov koryta, resp. jeho laterálnym pohybom. Jedným z klúčových faktorov, ktoré podmieňovali jeho vývoj, boli diferencované neotektonické pohyby. V pozdížnom smere mali vplyv na zmenu pôdorysnej vzorky koryta (Petrovszki, Szekély a Timár 2012), v priečnom smere zas v dôsledku asymetrického úklonu Podunajskej pahorkatiny na laterálne presúvanie koryta v smere na východ (Ištok a Ižof 1990). Ukazuje sa, že popri meandrovaní (Procházka a Pišút 2015) bol vo vývoji Váhu jedným z najpodstatnejších mechanizmov podmienených čiastočne tektonikou mechanizmus avulzií prvého rádu (Pišút et al. 2016). Avulziou prvého rádu chápeme náhly presun časti alebo celého koryta do inej trasy na nive. Spôsobená je lokálnym zvýšením časti koryta nad úroveň nivy v dôsledku jeho agradácie, tektoniky, zmeny prietokov alebo zahradením. Avulzia druhého rádu predstavuje náhly presun aktívneho koryta do staršieho, opusteného koryta (Lehotský, Kidová a Rusnák 2015).

DOI: https://doi.org/10.33542/GC2020-1-06 
Avulzie sú často dôsledkom práve tiltingu v priečnom smere doliny (úklonu reliéfu, $v$ tomto prípade generálneho úklonu Trnavskej pahorkatiny v smere na juhovýchod), prejavujú sa napr. asymetrickou polohou koryta $\mathrm{v}$ rámci nej, a vybreženie toku a následný vznik avulzného koryta sa deje v tomto smere (Holbrook a Schumm 1999). Na významný vplyv tohto mechanizmu na dolnom Váhu nepriamo poukazujú aj parametre miery vetvenia, resp. vel'ká výmera plôch bočných korýt, predovšetkým v úseku na Podunajskej pahorkatine ešte koncom 19. storočia (Novotný a Cebecauerová 2016). Nerovnomerné neotektonické pohyby (rýchlejší pokles územia v určitom úseku) môžu takisto spôsobit' avulziu prvého rádu. Výnimočná zmena hydrologického systému vyvolaná týmto mechanizmom bola popísaná z obdobia neskorého pleistocénu na rieke Tise (Timár, Sümegi a Horváth 2005). Niekedy môže byt’ avulzný proces tiež nepriamym následkom aktivít človeka v riečnej krajine (Pierik et al. 2018). K avulziám na dolnom Váhu dochádzalo vo vrcholoch dobre vyvinutých meandrov počas povodní. Za následok mali vznik bočných ramien. Bočné ramená boli často iba dočasné a postupne zanikali, niekedy však ako prietočné pretrvávali celé desat'ročia. Mechanizmom avulzie dochádzalo v minulosti aj k prekladaniu hlavného koryta Váhu (a iných tokov), a to aj v úsekoch dlhých desiatky kilometrov, čo môžeme považovat' za významné historické zmeny fluviálneho systému. Ciel'om predkladaného príspevku je na konkrétnych prípadoch načrtnút' niektoré významné zmeny riečneho koryta dolného Váhu, ktoré prebehli v historických dobách (pred zásadnejšími zásahmi človeka, ktoré by ovplyvňovali prirodzené fluviálne procesy), a tak zdokumentovat’ určujúci význam mechanizmu avulzií v správaní sa dolného Váhu. Súčast’ou práce je aj zdôvodnenie faktorov takéhoto správania sa rieky. Pri verifikácii pracovnej hypotézy o význame mechanizmu avulzií na študovanom úseku Váhu sme sa opierali najmä o staré mapy a v slovenskej geografii relatívne slabo využívanú onomastickú analýzu. V tomto kontexte jej aplikáciu môžeme považovat' za inovatívnu a overenie možností jej využitia, resp. obmedzení v historickej fluviálnej geografii, za čiastkový ciel'.

Fluviálny systém dolného Váhu sme študovali v období 16.-19. storočia z dôvodu, že proces avulzie a vznik bočných korýt je značne limitovaný činnostou človeka. Využívanie alúvia predovšetkým na pol’nohospodársku činnost' a potreba ochrany majetku pred povodňami a laterálnou eróziou mala za následok postupné systematické budovanie hrádzí, cielené zneprietočňovanie bočných ramien, reguláciu meandrov (ako kritických miest pre vybrežovanie počas povodní) ap. Toto všetko spôsobilo postupne pokles uplatňovania sa avulzií 1. rádu na Váhu, a to najskôr na Podunajskej rovine, postupne aj na Podunajskej pahorkatine (Procházka 2017).

\section{Metódy}

Hlavným informačným zdrojom použitým v práci boli rôzne staré mapové diela, ale aj aktuálne mapy a ortofotomapa (CEPRLK 2015). Riečny systém Váhu bol sledovaný v historických obdobiach, predovšetkým v 18. a 19. storočí, ked’že zo 16. - 17. storočia existuje z tohto regiónu len menšie množstvo starých máp. Tieto sú bud' málo presné, schematické, malých mierok alebo vel'komierkové, ktoré pokrývajú len malú čast' územia (Pišút et al. 2016).

Na vytvorenie obrázkov 1 a 3 sme využili mapu druhého vojenského mapovania (Jankó, Oross a Timár 2005), ktorá zachytáva stav hlavného koryta, bočných čiastočne prietočných alebo už neprietočných ramien na tomto mapovom diele (r. 1838 - 1840). Pri tvorbe obrázku 4 sme z druhého vojenského mapovania vychádzali len pri vtedajšom hlavnom koryte Váhu a Nitry. Avulzné korytá zobrazené na mape v čase druhého vojenského mapovania už neboli prietočné, rekonštruované boli za pomoci aj d’alších mapových diel (najmä Dunajského mapovania z r. 1824 - 1826; MOL 2006), resp. identifikované aj v súčasnom teréne podl'a ortofotomapy (CEPRLK 2015). Účelom bolo zachytit' ich pôvodný priebeh podl'a rôznych podkladov v čo najväčšom rozsahu. Okrem toho sme využili aj niektoré d'alšie mapové diela, ktoré zobrazujú len čast' územia, resp. v niektorých prípadoch neboli pre ich dostatočnú presnost' georeferencované. Tieto sú uvedené v zozname máp. Z dostupných starých máp (okrem spomínaných diel predovšetkým z pôvodných katastrálnych máp) ako aj s využitím najmä topografických máp 
rôznych mierok z 20. storočia sme excerpovali a analyzovali v dotknutých regiónoch toponymá, špeciálne hydronymá, ktoré nám výrazne pomohli pri rekonštrukcii trás korýt, resp. identifikácii ich významu (Pišút 1997). Pri niektorých interpretáciách sme vychádzali aj z onomastických prác z regiónu (Hladký 2011, resp. Hladký 2012).

$\mathrm{V}$ práci nie je zaradený digitálny model reliéfu vzhl’adom na skutočnost', že reliéf v tejto časti Podunajskej roviny je minimálne vertikálne rozčlenený, mimoriadne plochý a navyše brehy pôvodných korýt sú do značnej miery zotreté orbou, o čom sme sa presvedčili aj priamo v teréne.

\section{Výsledky a diskusia}

\section{Pravý breh Váhu}

Asi najvýznamnejším dnes už neexistujúcim pravostranným ramenom Váhu na Podunajskej rovine, ktoré bolo prietočné ešte $v$ historických dobách, je rameno označované ako Holt Vág (mad'. Mŕtvy Váh), so začiatkom pri Král'ovej nad Váhom a ústím pri Nedede (obr. 1). Dodnes je čiastočne sledovatel'né na leteckých snímkach, dobre sa zachovalo najmä v úseku medzi Tešedíkovom a Vlčanmi. Význam tohto ramena bol nepochybne vel'ký, ked’že po ňom prechádzala hranica medzi Bratislavskou stolicou a Nitrianskou stolicou. Chotárna hranica čiastočne sledovala rameno Holt Vág ešte aj v 19. storočí na mape druhého vojenského mapovania. Rameno zrejme existovalo dlhšiu dobu, o čom svedčí vyvinutá meandrujúca pôdorysná vzorka, teda úsek koryta s vysokým indexom sinuozity (Váh na tomto úseku dosahoval dížku cca 28 km, zatial' čo koryto Holt Vág 40 km). Po 3,5 km od Král’ovej nad Váhom, kde sa Holt Vág stáčal smerom na juh k Diakovciam, sa z neho odčleňovalo rameno, ktoré podl'a stavu na historických mapách bolo zrejme mladšie, označované bolo tiež ako Holt Vág, resp. Perna a ústilo do Dudváhu ned'aleko Král'ovho Brodu. Tento úsek (medzi Král'ovou nad Váhom a Král’ovým Brodom) spomína ako rameno Holt Vág Macháček (1935). Z ramena Holt Vág sa malo ešte oddel'ovat' rameno, ktoré „mizlo v močariskách pri Diakovciach“, čo je vlastne vetva, po ktorej prechádzala hranica medzi stolicami (Macháček 1935).

Zaujímavé je d’alšie pravobrežné rameno Váhu a predovšetkým jeho pravdepodobná súvislost' so zmieňovaným ramenom Holt Vág. Ide o rameno na druhom vojenskom mapovaní označované ako Dernye Árok (mad'. jarok Derňa), ktoré sa odčleňovalo od Váhu už na Podunajskej pahorkatine medzi Siladicami a Varovým Šúrom v mimoriadne vyvinutom meandri a neskôr pokračovalo do Dudváhu ako Holt Vág/Perna. Takisto ako skôr spomínané rameno aj Dernye Árok (d’alej „Derňa“) sa vyznačovalo značne meandrujúcim korytom a dosahovalo dížku viac ako $47 \mathrm{~km}$. Rameno je zakreslené už na Laziovej mape Uhorska z roku 1556. Súvisle zakreslené je na Mikovíniho mape Bratislavskej stolice z roku 1735.

Prehl'adnost' situácie v tejto časti dolnovážskej nivy komplikuje ešte rameno označované ako Sárd B. (mad’. Šárd), ktoré sa odčleňovalo z Dudváhu pri Majcichove, tieklo v priestore medzi Derňou a Dudváhom západne od Galanty a ústilo do Dudváhu medzi Hornými Salibami a Dolnými Salibami. Zo Šárdu sa napokon odčleňovalo pri Vel'kej Mači rameno s názvom Csipkésd Árú/Csipkésd Árok, ktoré sa stráca na mapách pri Galante, ktorú obtekaloz východu, s najväčšou pravdepodobnost'ou ale ústilo do Derne. Na základe hydronymickej analýzy, ale aj priestorových súvislostí, sa prikláňame k názoru, že ramená Derňa a Penna Flus/Holt Vág pôvodne tvorili jedno pravostranné rameno Váhu (so začiatkom pri Siladiciach a ústím pri Nedede). Potvrdzujú to pôvodné názvy už z 13. storočia, ktoré sa používali pre pomenovanie neskoršej Derne - fluuium Pinna, Pinnam fluuium, fluvium Pinna (Hladký 2012). Autor uvádza, že názov Derňa sa používal v severnej časti objektu, Pena zase v južnej. Objavuje sa tiež názov Perna, ktorý mohol byt' podl'a neho snahou o hláskoslovné vyrovnanie názvov Derňa a Pena (Pena - Perna - Derňa). Označenie Pena/Penna pre Holt Vág figuruje ešte aj v 17. a 18. storočí v urbári Diakoviec (OK 2018), ako aj na mape prvého vojenského mapovania. K diferenciácii dvojice názvov Derňa a Pena mohlo dôjst' po zmene hydrografickej situácie, ked' Derňa smerovala na západ do Dudváhu, rovnako však skôr, nakol'ko názvy dlhších vodných tokov tohto typu mali často lokálnu onymickú platnost' (Hladký a Závodný 2015). 


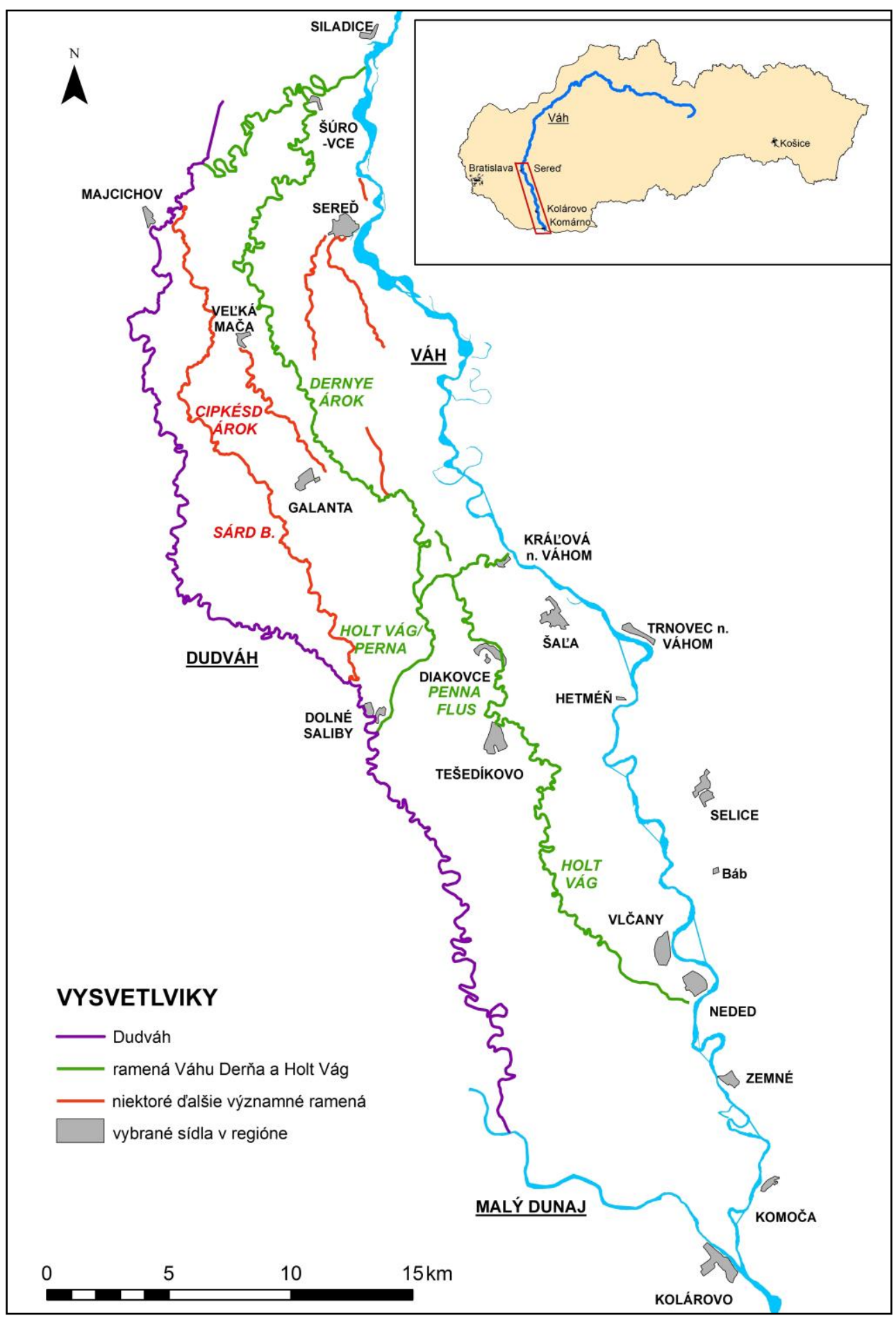

Obr. 1. Rekonštrukcia najvýznamnejších pravostranných bočných ramien Váhu v úseku Siladice - Kolárovo a ich priestorový súvis s Dudváhom;

Zdroj: Jankó, Oross a Timár (2005) 
Pokračovanie Derne do Holt Vágu naznačuje aj kratší úsek depresie od Derne pred jej ohybom na JJZ orientovaný v smere toku Holt Vágu. Názov Pena/Penna používaný pre Holt Vág poukazuje na skutočnost', že Derňa sa pôvodne spájala s Mŕtvym Váhom (Hladký 2011). K zmene hydrografickej situácie mohlo dôjst' pri mohutnej avulzii pri Král'ovej nad Váhom, pri ktorej sa vody Váhu prevalili cez vtedy už možno len periodicky prietočnú Penu až do Dudváhu.

Táto situácia by analogicky zodpovedala významnej zmene hydrografickej siete na Žitnom ostrove, ked' Malý Dunaj pravdepodobne počas extrémnej povodne vytvoril 16 km dlhý nový úsek koryta, čím zmenil trasu Dudváhu. Dudváh dovtedy tiekol dnešným dolným Žitným ostrovom a ústil do Váhu pri Kameničnej (Pišút et al. 2010).

Zaujímavý je predpoklad, že Pena (v celej dížke medzi Šúrovcami a Nededom) bola pôvodne vel'kým súvislým ramenom Váhu, načo poukazuje pravidelné používanie latinského termínu fluvius; sekundárnost' tohto ramena sa natol'ko nepocit'ovala, čo naznačuje aj variant Alte Waag (nem. Starý Váh) (Hladký 2011). Stretávame sa aj s názorom, že rameno Holt Wág bolo do 12. storočia nesporne hlavným tokom Váhu (Ištok a Ižof 1990). Istou indíciou potvrdzujúcou tento predpoklad môže byt' aj pôvodný názov obce Diakovce, ktorá leží pri tomto ramene - Wag (Váh), ktorý je doložený zo začiatku minulého milénia (Sedlák 2000). V prípade úseku Peny na Trnavskej pahorkatine by to bolo v súlade s tendenciou Váhu presúvat' $\mathrm{v}$ tomto regióne koryto smerom na východ.

Osobitný význam mal avulzný mechanizmus na vyšších úsekoch proti smeru toku Váhu, kde mala rieka vyššiu energiu a na niektorých miestach mala tendenciu nadobúdat migrujúcu pôdorysnú vzorku. Ako príklad uvádzame úsek Váhu medzi Ducovým a Moravanmi nad Váhom ned'aleko Piešt’an, kde v 18. storočí došlo k významnej zmene koryta. Na obr. 2 si môžeme všimnút', že v roku 1770 Váh na tomto úseku vytváral parametricky (šírkou koryta) dve približne rovnocenné korytá. Jedno z nich tieklo pod úpätím Považského Inovca v blízkosti obce Ducové a d’alej na juh v susedstve Moravian nad Váhom, kde sa nachádzal aj sútok oboch ramien, druhé smerom na západ od neho.

Vzhl'adom na poznanie charakteru úseku Váhu v okolí Piešt’an v tomto období (migrujúca pôdorysná vzorka) predpokladáme, že jedno z korýt pôvodne plnilo úlohu hlavného koryta a druhé vzniklo následne avulzným mechanizmom a postupne prebralo funkciu hlavného koryta. Predpoklad takejto genézy potvrdzuje aj polohová situácia koryta, kde na spomínanej mape z roku 1770 Váh vytvára l’avotočivú zákrutu a pokračuje v smere pravdepodobne staršieho ramena po úpätí pohoria. K vytvoreniu neskoršieho hlavného koryta došlo avulziou v spomínanej l'avotočivej zákrute pri niektorej z väčších povodní pravdepodobne v 18. storočí. Podrobný prehl'ad historických povodní v tomto regióne bol spracovaný v samostatnom príspevku (Pišút et al. 2016). Známe sú viaceré vel'ké povodne z tohto regiónu, napr. aj v 70. rokoch 18. storočia (napr. 18. 2. 1775, 11. - 18. 8. 1779, 26. 11. 1779), hoci k tejto zmene koryta muselo dôjst' o dost' skôr, ked'že je zaznamenaná už na mape z roku 1770. Skutočnosti, že k tejto zmene došlo skôr nasvedčuje aj fakt, že na dnešnom hlavnom koryte je na mape z roku 1770 zakreslený dobre vyvinutý meander, ktorý síce ešte bol prietočný, ale už s pretrhnutou, prípadne prekopanou meandrovou šijou. Nie je vylúčené, že obyvatelia Ducového, prípadne d'alších obcí v tomto priestore neskôr po vzniku avulzného koryta dopomohli regulačnými opatreniami k postupnému zneprietočneniu ramena v blízkosti ich obcí, nakol'ko laterálne aktívne koryto ohrozovalo cestu severojužného smeru spájajúcu tamojšie obce. Motivovat' ich k tomu mohli aj spomínané vel'ké povodne v 70. rokoch 18. storočia. Pri jednej z týchto povodní napr. došlo aj k zničeniu ned’alekej obce Baková (dnes v katastrálnom území obce Drahovce, mimo náš mapový výrez), ktorá bola opustená a nikdy nebola obnovená (Manák 2010). Ak bolo takéto opatrenie vykonané, došlo k nemu niekedy pred rokom 1782. Podobné opatrenia neboli na Váhu výnimočné, známe sú už zo 17. storočia z vtedajšieho Mestečka pri pevnosti Leopoldov, kde obyvatelia zneprietočňovali bočné korytá v okolí pevnosti (Pišút et al. 2016). 


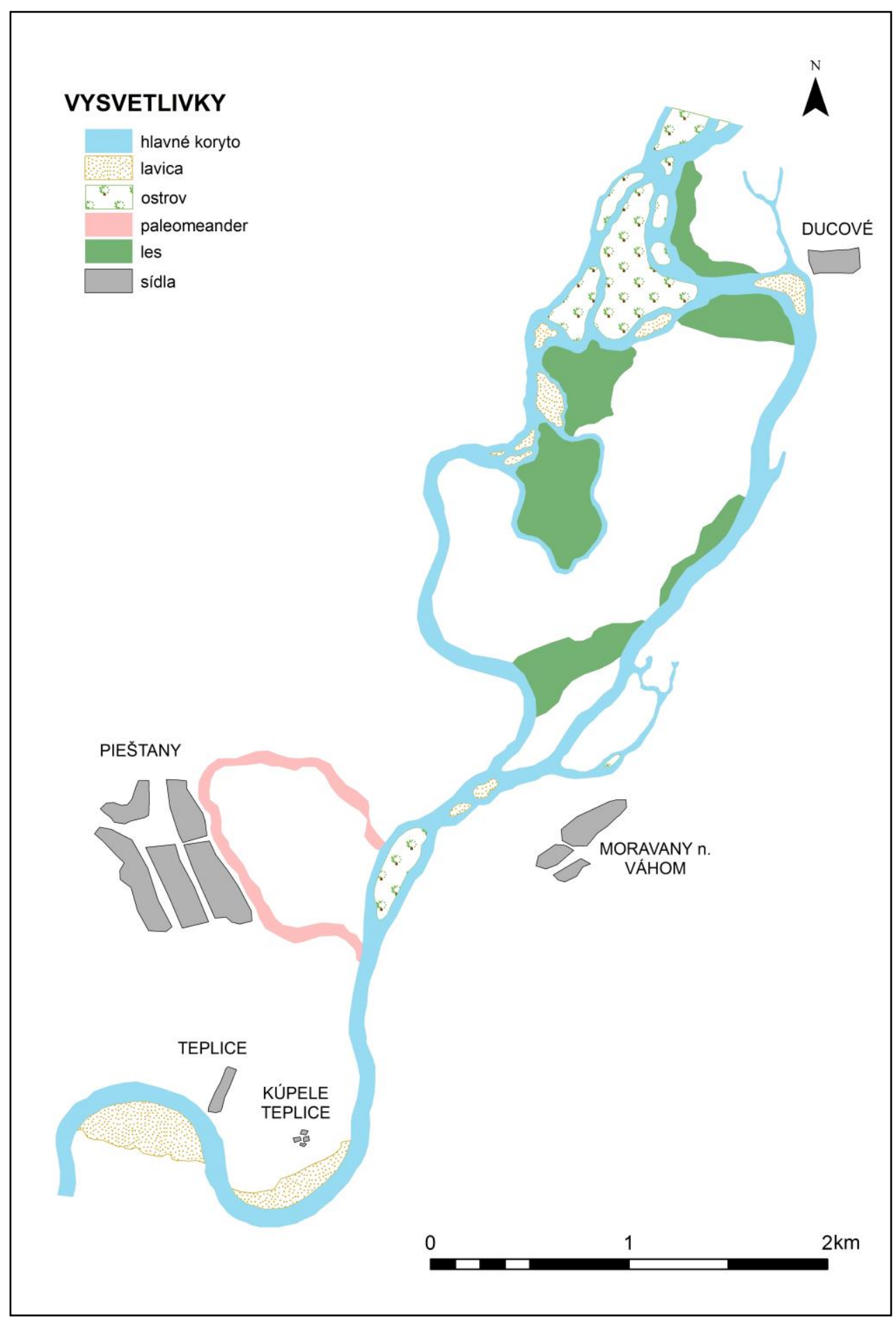

Obr. 2. Ramenný systém Váhu v úseku Ducové - Teplice v roku 1770; Zdroj: mapa č.l v zozname použitých máp 


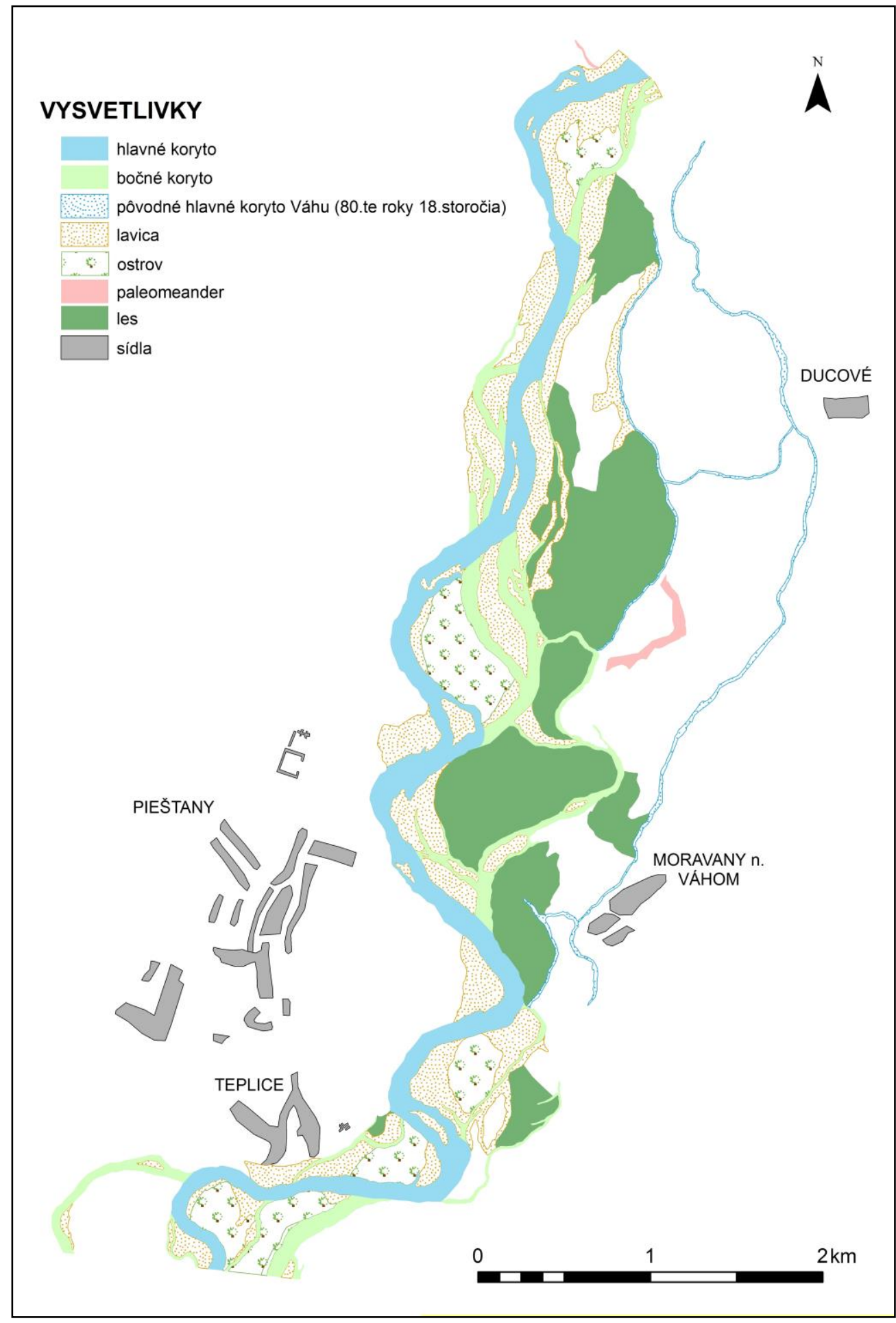

Obr. 3. Ramenný systém Váhu v úseku Ducové - Pieštany v prvej polovici 19. storočia; Zdroj: Jankó, Oross a Timár (2005) 
Koncom 18. storočia, prípadne začiatkom 19. storočia, došlo k zásadnej zmene - zneprietočneniu l'avostranného, vtedy už bočného (parametricky menej významného), pôvodne hlavného ramena Váhu, ktoré malo na mape prvého vojenského mapovania dížku približne $5,5 \mathrm{~km}$. Na tejto mape je ešte znázornené ako prietočné. Už v rokoch 1782 - 1784 však bolo viditel'ne parametricky menej významné. Na mape druhého vojenského mapovania však už bolo neprietočné (obr. 3) a existovalo ako močaristá depresia. Na tejto mape je pekne zachovaný aj zvyšok vyššie spomínaného parametricky extrémneho paleomeandra v strednej časti územia, ktorý už v roku 1770 postupne zanikal, hoci bol ešte prietočný.

Na rozdiel od ostatných uvádzaných pravostranných úsekov $\mathrm{k}$ avulzii v tomto prípade nedošlo v smere tiltingu Trnavskej pahorkatiny, ale v opačnom smere - na západ. Bolo to podmienené polohovou situáciou úseku, ked’že pôvodné koryto tieklo po úpätí Považského Inovca, kde ukladalo materiál, a k avulzii počas povodne mohlo dôjst' len $\mathrm{v}$ tomto smere.

\section{Lavý breh Váhu}

Nemenej zaujímavé sú aj avulzné korytá na l’avom brehu dolného Váhu. Na základe analýzy starých aj súčasných máp a ortofotomapy sme v priestore geomorfologickej jednotky Martovská mokrad' (čast' Podunajskej roviny) medzi súčasnými korytami (agradačnými valmi) Váhu a Nitry identifikovali staršie pôvodné koryto Váhu (obr. 4). Používame preň pracovný názov Lodná cesta, čo je slovenský preklad miestneho mad'arského hydronyma Hajó Út z mapy druhého vojenského mapovania. Dlhší úsek tohto koryta je dobre identifikovatel'ný na viacerých starších mapách predovšetkým z 19. storočia (dunajské mapovanie, druhé a tretie vojenské mapovanie). Na skutočnost', že išlo o hlavné koryto Váhu, poukazujú najmä morfometrické parametre tohto ramena - šírka meandrového pásu, rádius meandrov, meandrová dížka, ako aj šírka dna týchto starých riečnych foriem, ktorá dosahuje parametre hlavného koryta Váhu. Tento úsek podl'a analýzy začínal s najväčšou pravdepodobnost’ou v blízkosti obce Neded v polohe ako ju poznáme v súčasnosti, problematický je ale jeho d'alší priebeh, resp. miesto, kde bud' ústilo do Dunaja alebo pokračovalo v neskoršej známej trase. V úseku, v rámci ktorého je toto koryto dobre sledovatel'né, tok vytváral agradačný val, ktorý je zretel'ný aj z využivania krajiny, resp. krajinnej pokrývky ešte v minulosti. Tak ako v prípade viacerých iných tokov na Podunajskej rovine, ktoré pretekajú v minulosti zamokrenými depresiami (porovnaj napr. úsek pôvodného Dudváhu na Žitnom ostrove a jeho agradačný val), pozdíž agradačných valov, často v bezprostrednej blízkosti aktívneho toku sa vyskytovala orná pôda, polia, zatial' čo po stranách valu boli bud' priamo močiare, alebo vlhké lúky. Už prevýšenie $0,5-1 \mathrm{~m}$ umožňovalo exploatovat' územie takýmto spôsobom, zatial' čo v pril'ahlých zníženinách výška hladiny podzemnej vody neumožňovala pestovanie pol'ných kultúr. Š́rka agradačného valu Lodnej cesty zodpovedá intervalu hlavného koryta Váhu 0,5 - 3 km, ktorý je známy aj z literatúry (Ištok a Ižof 1990). V prípade Lodnej cesty dosahuje šírku do $2,3 \mathrm{~km}$, čo približne zodpovedá aj vtedajšiemu aktívnemu korytu Váhu v tomto regióne. Náš predpoklad potvrdzuje aj tvrdenie Lukniša (1969), podl'a ktorého ohyb rieky Nitra pod Novými Zámkami (ned’aleko Lodnej cesty) bol podmienený agradačným valom Váhu. Aktívne koryto Váhu v dnešnej polohe (ktorá sa nezmenila už minimálne od 19. storočia) je vzdialené od tohto ohybu takmer $7 \mathrm{~km}$, preto $\mathrm{v}$ priestore medzi súčasným korytom Váhu sa dá predpokladat' $v$ minulosti existencia minimálne jedného, ak nie dvojice paralelných agradačných valov Váhu. Jedným z nich je práve val Lodnej cesty. Popri úseku Lodnej cesty, ktorý bol zachovaný/identifikovatel'ný v 19. storočí, existovali dva staršie odstavené meandre, ktoré prislúchali tomuto ramenu, jeden na l'avom a jeden na pravom brehu. Okrem toho v priestore medzi súčasnými korytami Váhu a Nitry existuje minimálne jeden spol'ahlivo identifikovatel'ný meander hlavného koryta Váhu, ktorý mohol byt’ súčast’ou nami riešeného ramena, a kratší úsek trojice meandrov na l'avom brehu Nitry, ktoré parametricky takisto zodpovedajú hlavnému korytu Váhu (obr. 5). Tie boli bud' súčast'ou Lodnej cesty, alebo ešte staršieho ramena. Napokon existenciu staršieho agradačného valu Váhu v priestore medzi súčasným korytom Váhu a Nitry spomínajú aj Lukniš a Bučko (1953). Tento mal Váh opustit', aby vytvoril súčasný mladoholocénny val, vyvýšený nad okolitým terénom, depresiami max. $2-3 \mathrm{~m}$. 


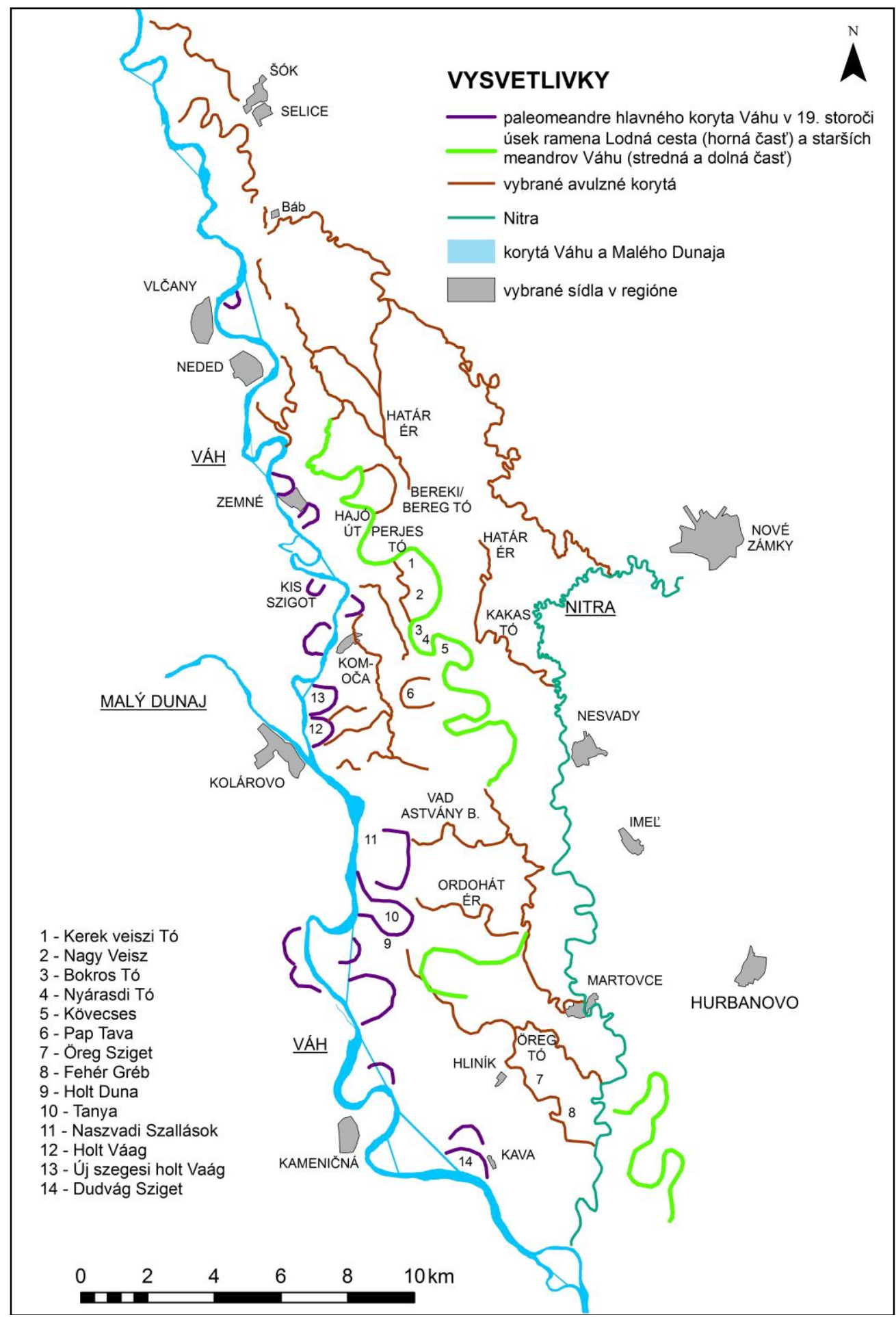

Obr. 4. Rameno Lodná cesta, vybrané avulzné korytá a niektoré miestne názvy regiónu medzi Váhom a Nitrou; Zdroj: MOL (2006), Jankó, Oross a Timár (2005) 
Na význam tohto ramena okrem jeho parametrov a agradačného valu nepriamo poukazuje aj bohatý súbor hydroným tohto územia. Pozoruhodný je najmä spomínaný názov Hajó Út (Lodná cesta), ktorý poukazuje na skutočnost', že rameno bolo splavné lod'ami, nie plt’ami. Takto splavné mohlo byt' len hlavné koryto Váhu. Tento predpoklad je v súlade s konštatovaním Medňanského (2007), ktorý vo svojej práci - prvýkrát vydanej v roku 1826 - spomína, že v Nedede existoval lodný prístav, kde sa prekladal tovar. Židovskí obchodníci z regiónu sa sem vracali s tovarom $\mathrm{z}$ Budapešti na prenajatých dunajských lodiach, vykladali ho a panoval tu vtedy čulý ruch. Ďalší miestny názov používaný na viacerých mapách pre jeden z meandrov koryta Lodná cesta bol Nagy Veisz (mad'. vel'ká vejsa) a súvisí s rybolovom na Dunaji a v dolných úsekoch jeho väčších prítokov. Práve tu sa totiž v historických dobách lovili vyzy, najväčšie dunajské ryby, ktoré dosahovali hmotnost' aj niekol'ko sto kilogramov.

Obec Nesvady, v ktorej chotári sa nachádzajú zvyšky nami riešeného ramena aj s miestnym názvom Nagy Veisz, bola preslávená lovom výz na Dunaji, vd’aka ktorému získala v 15. storočí postavenie mestečka (Obec Nesvady 2018). Vyzy Nesvadčania predávali na panovnícky dvor do Viedne, ale aj až do Regensburgu. Motív z lovu výz sa dostal aj do obecného erbu, ktorého súčast'ou je dodnes (Püspöki Nagy 2001). V erbe je znázornená kolová pasca s vyzou a zlatá farba štítu, poukazujúca na „zlaté obdobie“ obce. Pochopitel’ne to neznamená, že vyzy lovili v nami sledovanom koryte, naopak, existujú historické doklady, že sedze na vyzy mali napr. v jednom z meandrov už vtedy existujúceho Vážskeho Dunaja poniže Kolárova (Alapy 1994). Dozvedáme sa o tom vd’aka prirodzenému odrezaniu tohto meandra v roku 1581, vd'aka ktorému prišli Nesvadčania o čast' svojich príjmov a žiadali o skrátenie povinnosti platit' dane ostrihomskému arcibiskupovi. V tom istom zdroji sa spomína, že Nesvadčania mali len túto jednu sedzu, okrem nej však mali ešte jednu vejsu. Vejsy boli kolovité pasce na lov väčších výz, boli pod aktívnym dohl'adom rybára, zatial' čo sedze boli takisto pasce, ale na menšie vyzy, aj na menších, bočných ramenách, vytvorené z prútia. Existujú záznamy tiež o tom, že menšie vyzy, ktoré Nesvadčania odchytili, chovali $\mathrm{v}$ špeciálnych rybníkoch. Mohlo íst' práve o čast' ramena Lodná cesta, pre ktorú sa používalo toponymum Nagy Veisz. V takom prípade však muselo byt' v tej dobe ešte aspoň čiastočne prietočné, ked’že vyzy sú reofilné (prúdomilné) ryby. Nie je vylúčené, že tu nechovali priamo vyzy, ale menšie jeseterovité ryby, ktoré sa lovili obdobným spôsobom. V každom prípade miestny názov Nagy Veisz je svedectvom o význame tohto ramena, ktoré nepochybne plnilo úlohu hlavného koryta Váhu. Napokon ned'aleko miesta, kde sa objavuje spomínaný miestny názov, sa používal aj d’alší obdobný - Kerek veiszi Tó, kde takisto figuruje vejsa (Balon 1967).

$\mathrm{S}$ motiváciou rybolovu $\mathrm{v}$ miestnych názvoch sa stretávame aj inde v rámci tohto regiónu. Spomenieme príklad z trojice pravdepodobne vážskych meandrov na l'avom brehu Nitry. Pre jeden z nich sa používal mad'arský miestny názov Kárászos, ktorý poukazuje na skutočnost', že sa tu lovili karasy. Tie na rozdiel od jeseterovitých rýb znášajú stojaté vody, vrátane prostredia zazemňujúcich sa ramien v iniciálnych štádiách (Holčík a Hensel 1971). V prípade týchto meandrov proces zazemňovania mohol však prebiehat' rýchlejšie (skôr), ked'že tieto meandre sú na rozdiel od hornej časti Lodnej cesty v úseku, kde ich ovplyvňovali aj povodne vyvolané Malým Dunajom.

Miestny názov Sporné pri Hajó Út poukazuje na skutočnost', že starší odrezaný meander sa ocitol na l'avom brehu Lodnej cesty, teda v chotári inej obce, čiže hranica chotára musela íst' po Lodnej ceste a zároveň toto územie muselo byt' z pravého brehu po prerezaní meandrovej šije t’ažko dostupné (Pišút 1997).

Dalším problémom týkajúcim sa tohto mikroregiónu je priebeh hranice medzi Komárňanskou stolicou a Nitrianskou stolicou. Prebieha paralelne popri ramene Lodná cesta na východ od neho. Stretávame sa tu s miestnym názvom Határ ér (mad'. Hraničný potok/rameno). V čase konštituovania tohto miestneho názvu teda existujúce rameno už bolo sekundárne. Skutočnost', že po ňom prechádzala hranica medzi stolicami, však poukazuje na jeho význam. Predpokla- 
dáme, že aj v tomto priestore existovalo hlavné koryto Váhu, ktoré bolo opustené a vzniklo rameno Lodná cesta, ktoré tieklo paralelne popri pôvodnom agradačnom vale Hraničného ramena. Zodpovedali by tomu aj údaje o šírke pôvodných agradačných valov a o tom, že usmernili tok Nitry v tomto regióne. Hranice medzi stolicami sa konštituovali v 11. - 12. storočí, v tomto čase teda mohlo existovat' Hraničné rameno ako hlavné koryto Váhu, neskôr vzniklo avulzným mechanizmom rameno Lodná cesta, ktoré zaniklo pravdepodobne v 15., najneskôr v 16. storočí. Zodpovedalo by to aj údajom o dížke vytvárania agradačných valov Váhu. Jedna perióda vzniku a tvorby agradačného valu (Váhu), dokial' rieka v istom štádiu vývoja, resp. najmä pri mimoriadnej povodňovej udalosti neskízne do pozdĺžnej zníženiny sledujúcej agradačný val a vytvorí nové koryto a základ nového valu, trvá desiatky až stovky rokov (Ištok a Ižof 1990). K d’alšej obdobnej významnejšej zmene koryta Váhu v tomto regióne neskôr už nedošlo, ked’že rástol rozsah a kvalita budovaných protipovodňových hrádzí a vôbec zásahov človeka do koryta, čím človek tieto tendencie Váhu limitoval.

Štúdium Hraničného ramena ako aj celého mikroregiónu medzi Komočou, Martovcami a Komárnom je problematické, a to vzhl'adom na skutočnost', že po prevalení Malého Dunaja do Váhu pri Kolárove došlo k významnej zmene prietokových pomerov. Dedukujeme to na základe parametrov korýt vtedajšieho Váhu a Malého Dunaja, táto problematika si však bude vyžadovat' systematickejšie podrobné štúdium v samostatnom príspevku. Zmena prietokových pomerov sa prejavila aj na správaní sa úseku vážskeho Dunaja. Opakovane tu vznikali kratšie avulzné ramená, ktoré rozplavovali pôvodné štruktúry riečnej krajiny, čo st’ažuje rekonštrukcie pôvodných korýt. Prehl'adnost' komplikuje aj mimoriadne kl'ukaté rameno, resp. sústava ramien parametricky menej významných, ktoré obtekali Hraničné rameno z východu a ústili do Nitry. Dobre vyvinuté boli najmä juhovýchodne od Selíc. Ich pôvod sa nám dostatočne kredibilne nepodarilo doposial' dokázat', nie je vylúčené, že vznikli činnost'ou potoka pritekajúceho z Nitrianskej pahorkatiny, ktorý bol neskôr presmerovaný vybudovaním siete kanálov.

Tento variant sa nám zdá vzhl’adom na ich parametre nepravdepodobný, preto sa prikláňame k názoru, že ich vznik podmienila rieka Váh, čo je podložené aj v regionálnej literatúre (Kolečáni 1998). Preukázaná je ich priestorová súvislost's avulzným ramenom Váhu, ktoré vznikalo v meandri pri Hetméni (výrazný ohyb Váhu poniže Šale), najprv tieklo západne od Š́ku a Selíc popri agradačnom vale Váhu a neskôr sa stáčalo na východ, kde už je možné na mapách z 19. storočia sledovat' priebeh týchto ramien až po ústie do Nitry. Práve v priestore, kde začínalo avulzné rameno, ned’aleko Selíc, existovala neskôr zaniknutá dedina Pieščany (Maslíková 2010); jej zánik mohol súvisiet's rozvojom ohybu pri Hetmíni a pravidelným vybrežovaním Váhu do tohto priestoru. So zmienkami vodného toku v tomto území sa stretávame aj v literatúre, kde sa spomína fluuium Piscanis, ktorého názov je odvodený od Pieščan (Šmilauer 1932; presná poloha tejto zaniknutej obce nám nie je známa). Ak sa preukáže, že súčast’ou tohto systému bolo aj jazierko Sógó (Šogo) pri majeri Báb južne od Selíc, tak zánik tohto ramena môžeme datovat' pred rok 1700 , ked'že $\mathrm{z}$ tohto roku máme záznamy už o ,jazierku“ Šogo (Kolečáni 1998). Je pravdepodobné, že tento systém súvisel aj s avulzným korytom, ktoré začínalo medzi Večou (čast' Šale) a Trnovcom nad Váhom, a tieklo d’alej na východ od súčasného koryta Váhu popri majeri Kis Jato (Malý Jatov). Zatial' čo spomínané koryto, ktoré sa oddel'ovalo pri Seliciach a tieklo smerom na Palárikovo, bolo preukázatel'ne avulzné, práve $\mathrm{v}$ tomto druhom prípade bol úsek ovplyvnený asi niektorým z potokov z Nitrianskej pahorkatiny, do ktorého sa prelievali vody Váhu počas avulzií medzi Večou a Trnovcom a neskôr sa obe vetvy spájali a vytvárali zložitý systém parametricky menších meandrov a na nižšom úseku takisto vytvárali zretel'ný agradačný val.

Čo sa týka avulzií na l’avobreží dolného Váhu, zdá sa, že okrem týchto dvoch spomínaných vetiev v posledných storočiach zohrávali významnú úlohu práve na úseku Vážskeho Dunaja. Dozaista sa tento efekt zosilnil najmä od vzniku sútoku Malého Dunaja a Váhu pri Kolárove. Pravdepodobne po tejto udalosti (alebo už skôr) vznikla dvojica parametricky výrazných me- 
androv, z ktorých jeden nesie miestny názov Holt Duna (Mŕtvy Dunaj), v súčasnosti maloplošné chránené územie Listové jazero. Pri niektorej z väčších povodní, pravdepodobne v 16. storočí, práve vd’aka týmto dvom meandrom vznikli dve najvýraznejšie avulzné korytá, ktoré mali cca $3 \mathrm{~km}$ takmer rovnobežkový priebeh a neskôr sa vlievali do ramena tečúceho paralelne s Nitrou a napokon v Martovciach do Nitry. Predpokladáme, že na vytvorenie svojich korýt využili terénnu predispozíciu - pôvodný meander staršieho hlavného koryta Váhu. Tieto ramená museli existovat' dlhodobo a mat' svoj význam, zakreslené sú už na malomierkových mapách zo 16. storočia a majú aj vlastné miestne názvy - Vad Astvány B. a Ordohát ér. Obe tieto ramená sa oddel'ovali z meandra označovaného ako Holt Duna, z nižšie situovaného z dvojice meandrov však takisto prebiehali avulzie. Avulzné korytá z tohto meandra končili v močiari Öreg Tó, vody ktorého stekali do Nitry. Všetky tieto ramená sú detekovatel'né ešte na mape druhého vojenského mapovania.

Na staršej mape (dunajské mapovanie) sme na l’avom brehu Váhu medzi Nededom a Kolárovom identifikovali minimálne d’alších šest' avulzných korýt, ktoré však neústili do ramena Lodná cesta, ale tiekli popri jeho agradačnom vale smerom na juh a neskôr sa napájali na zložitú siet' močiarov v tomto regióne. Začiatkom 19. storočia sa ako najmladšie javili avulzné korytá vzniknuté z vtedy už odstavených meandrov poniže Komoče. Avulzné koryto $\mathrm{v}$ posledných storočiach vybiehalo aj z meandra, ktorý takisto už v 19. storočí nebol prietočný a v súčasnosti ho kopíruje stredisková čast' obce Vrbová nad Váhom.

Zaujímavé je, že v prípade Zemného aj Kolárova sa spomína na stránkach obcí pôvodná poloha mestečiek na l'avom brehu Váhu vo vzdialenosti niekol'kých kilometrov, pričom neskôr došlo k ich presídleniu na súčasné miesta. V prípade Zemného (nie však Kolárova) sa špekuluje, že dôvodom boli turecké vpády a vôl'a obyvatel'stva chránit' sa pred Turkami. Nevylučujeme, že k zmene polohy obce došlo aj kvôli zmene polohy hlavného koryta Váhu. K zmene polohy Kolárova kvôli Turkom došlo takisto, ale len z l'avého na pravý breh, spomínané presídlenie prebehlo už predtým. Majer O. Guta sa na mape druhého vojenského mapovania nachádza na l'avom brehu Lodnej cesty. Presun starších dedín za Váhom je pravdepodobný, ked’že pri mnohých z nich sa z ich najstarších dejín spomína, že obyvatel'stvo sa živilo rybolovom. K presunu obce smerom na západ došlo aj v prípade Kameničnej (Keszegfalva).

Otázny je dôvod zániku dedín Aňala a Gég, ktoré ležali niekde v priestore Lodnej cesty. Ak by sme poznali presnejšie obdobie ich zániku a vek, kedy bolo rameno Lodná cesta aktívne, dalo by sa potvrdit'/vylúčit', že ich zánik je spojený s aktivitou tohto ramena. Ak zanikli v neskoršom období, čo však nepredpokladáme, ich zánik by súvisel so zvýšenou aktivitou úseku Váhu Kolárovo - Komárno.

Nesporná súvislost' medzi povodňami malej doby l’adovej a zániku neskôr neobnovenej dediny je ale v prípade obce Baková, ktorá ležala na pravom brehu Váhu ned’aleko Drahoviec na Podunajskej pahorkatine.

\section{Poznámky k trase koryta Lodná cesta}

Na základe analýzy historických máp a ortofotomapy z aktuálneho obdobia (CEPRLK 2015) vieme, že pôvodné hlavné koryto Váhu v priestore medzi dnešným Váhom a Nitrou, tzv. Lodná cesta (Hajó Út), začínalo pri Nedede, neznáme je ale jeho ústie do Váhu či Dunaja. Existujú dve reálne varianty jeho trasy v dolnej časti toku (obr. 5).

Prvý variant je približne v súlade s prácou Lukniša a Bučka (1953). Autori sa síce o prítomnosti hlavného koryta Váhu v tomto priestore podrobnejšie nevyjadrujú, ani nekonštatujú jeho význam, na geomorfologickej mape, ktorá je súčast’ou práce, však zakreslili agradačný val, ktorého priebeh je podobný, ako nami navrhovaná trasa A (obr. 5). V rámci tejto trasy je na mapách z 19. storočia ešte dobre rozlíšitel'ný minimálne jeden meander, ktorý parametricky zodpovedá hlavnému toku, vzhl’adom na svoju polohu však nezodpovedá súčasnému hlavnému korytu. Zároveň sú na tejto trase aj dve menšie osady - Kava a Hliník (vieme, že sídla 
v tomto regióne sa spravidla sústredili na agradačné valy, kvôli ochrane obyvatel'stva pred povodňami a prítomnosti vzhl'adom na topografiu potenciálne obrábatel'nej pôdy). Rameno Lodná cesta by v takom prípade začínalo pri Nedede a v trase súčasného koryta Váhu by pokračovalo približne od osady Kava.

Pozoruhodný je druhý variant (trasa B, obr. 5), ktorý predpokladá, že koryto Váhu sa tiahlo smerom na východ v doline Starej Žitavy. K tomuto predpokladu nás vedie prítomnost’ trojice meandrov, ktoré parametricky môžu zodpovedat' $v$ tejto lokalite jedine hlavnému korytu Váhu a nachádzajú sa na l'avom brehu neskoršej trasy rieky Nitra. Odtial'to mohol Váh tiect' len dvomi trasami - smerom na východ k Marcelovej a juhovýchod k obci Žitava (Zsitvató, mad'. ústie Žitavy), kde ústil do Dunaja (teda trasou Starej Žitavy), alebo v rovnakom smere ešte o čosi južnejšie, s ústím do Dunaja pri obci Iža. Na juh od trasy B sa totiž nachádza starý agradačný val s viacerými väčšími meandrami. $Z$ analýzy parametrov, polohy a orientácie meandrov na mapách a leteckých snímkach nie je podl'a nášho názoru možné vylúčit', že tieto meandre prislúchali hlavnému korytu Váhu. V literatúre sa však stretávame s názorom, že ide o starý agradačný val Dunaja, ktorý zatlačil Starú Žitavu viac na sever (Lukniš a Bučko 1953). Nevylučujeme ani variant s ústím pri Iži, tento by totiž dobre vysvetl'oval zmenu toku Nitry. Niektoré meandre na spomínanom agradačnom vale sa totiž vyskytujú blízko súčasného koryta Váhu - toto mohlo „načapovat'“ vtedajší tok Nitry, ktorý tiekol starým korytom Váhu.

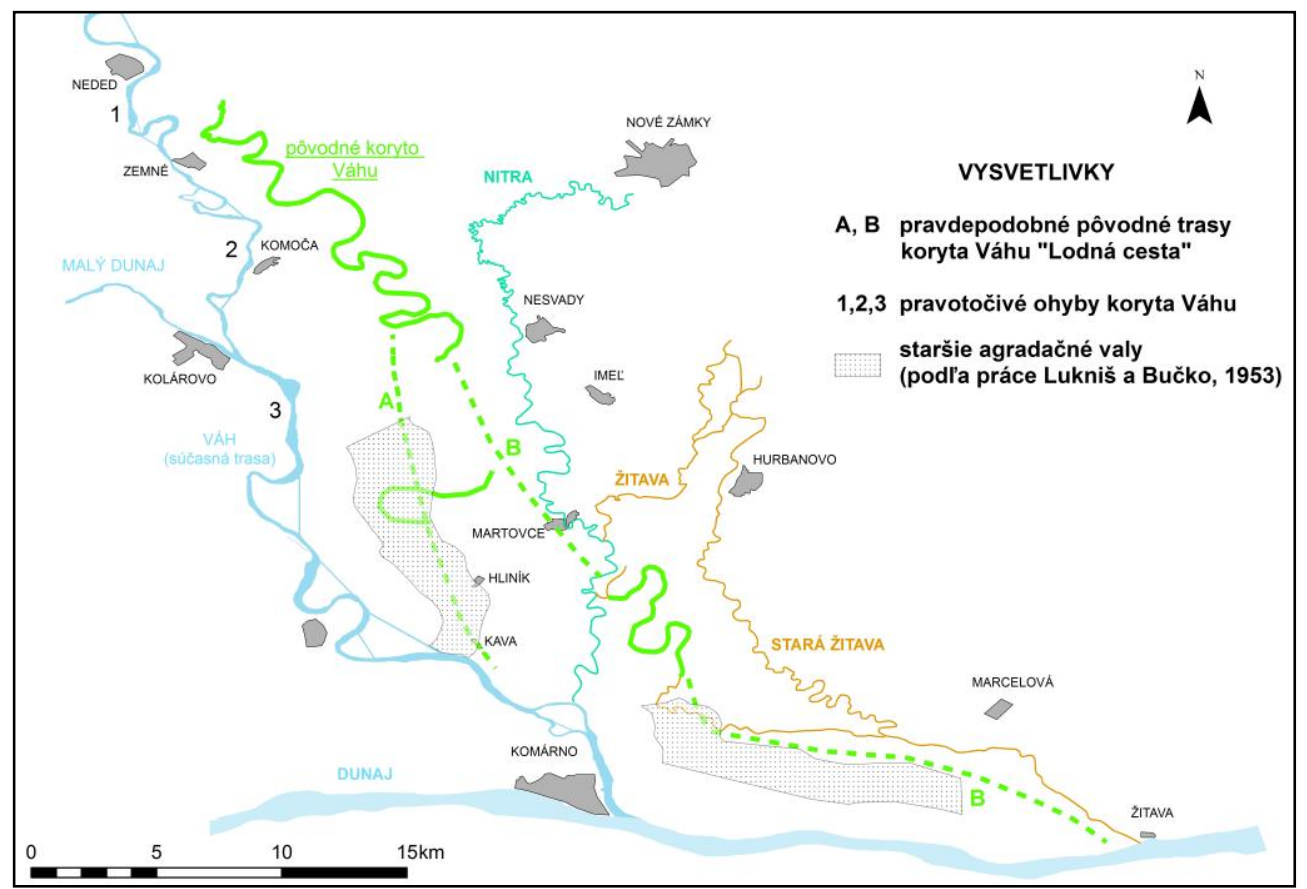

Obr. 5. Pravdepodobné trasy staršieho koryta Váhu „Lodná cesta“ v priestore Martovskej mokrade; Zdroj: Jankó, Oross a Timár (2005); trasy rekonštruované z viacerých podkladov podl'a popisu $v$ texte

Komplikovanú situáciu trasovania môžeme zhrnút’ nasledovne. Rameno Lodná cesta pravdepodobne tieklo od súčasnej osady Kava $\mathrm{v}$ dnešnej trase. V priestore medzi súčasným Váhom a Nitrou však existovalo ešte d'alšie rameno, ktoré pôvodne ústilo do Dunaja pri Žitave alebo Iži. V prvom prípade by doňho ústila rieka Žitava. Skutočnost', že korytom Starej Žitavy tiekla aj čast' vážskych vôd je nesporná, ešte na mapách z 19. storočia je evidentné, že avulzné korytá Váhu sa prelievali do Nitry a pokračovali aj na východ korytom 
Starej Žitavy. Túto skutočnost' vel'mi dobre dokumentuje aj mapa Johanna Hoffmana z r.1670 (mapa č. 2 v zozname použitých máp). Azda najhmatatel'nejším dôkazom je ale mapa Žitného ostrova tiež z roku 1670, ktorá okrajovo zachytáva aj toto územie a vyskytuje sa tu miestny názov Schütt Waag Flus (doslova Žitavský Váh; obr. 6). Otázkou zostáva, či toto rameno $\mathrm{v}$ trase $\mathrm{B}$ bolo len staršou trasou ramena Lodná cesta ( $\mathrm{k}$ avulzii došlo niekde na úrovni intravilánu Nesvád), alebo išlo o staršie paralelné rameno, ktoré tieklo na východ od Lodnej cesty. K tejto úvahe nás vedie pozoruhodný priebeh hranice medzi Komárňanskou stolicou a Nitrianskou stolicou, ktorá prebieha cez močiare východne od Lodnej cesty vo vzdialenosti, ktorá by mohla zodpovedat' paralelnému korytu a vyskytuje sa tu miestny názov Határ ér (Hraničné rameno). Názov ér poukazuje na skutočnost', že v čase vzniku názvu bolo rameno parametricky (šírkou, možnost'ami prebrodit' ho) už menej významné, išlo však ešte o prietočné rameno (Pišút 1997). Trojica meandrov na l'avom brehu Nitry je však v každom prípade staršia, naznačujú to miestne názvy spomínané vyššie. V každom prípade by si táto problematika vyžadovala d’alší výskum, podrobnú historicko-geografickú analýzu, resp. prírodovedný terénny výskum spojený s absolútnym datovaním spomínaných meandrov.

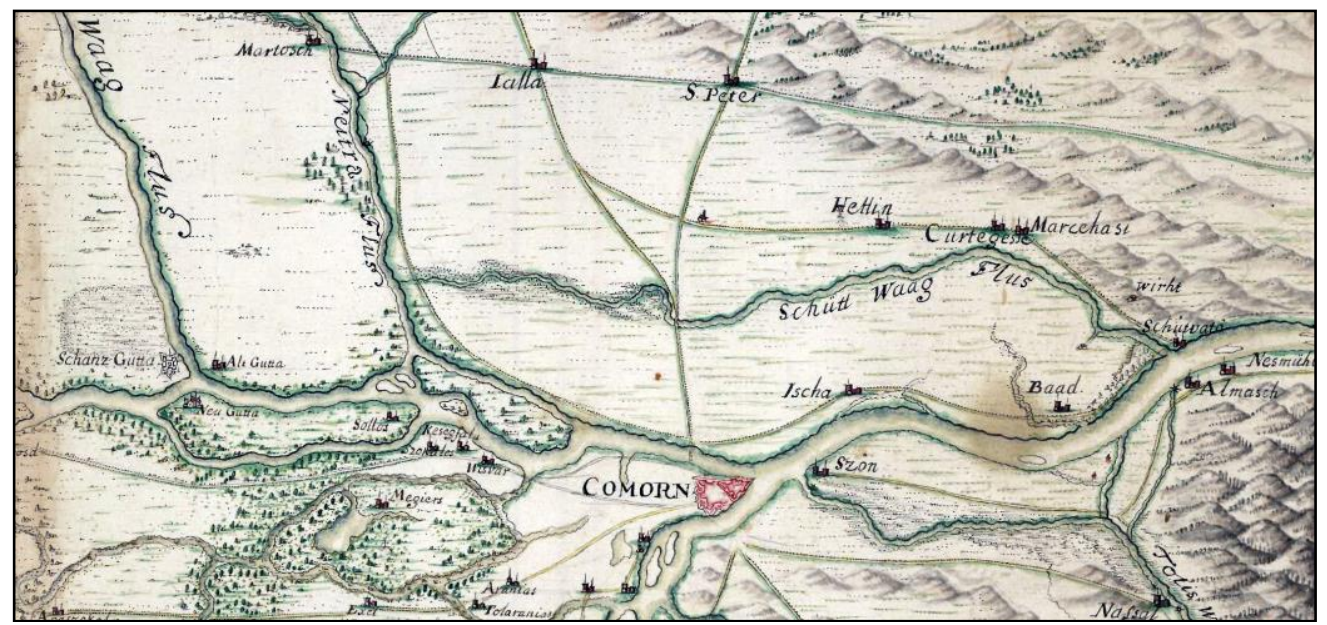

Obr. 6. Rameno Schütt Waag (Žitavský Váh) v roku 1670;

Zdroj: mapa č. 3 v zozname použitých máp

Čo sa týka prekladania koryta Váhu v tomto priestore v minulosti, bolo podmienené dvojicou antagonistických procesov. Na jednej strane to bola tendencia koryta presúvat' sa smerom na západ, podmienená tektonicky, na druhej strane limitujúce exogénne faktory - mohutný agradačný val Dunaja a komplikované zmeny riečnych sietí v tejto časti Podunajskej nížiny. Efekt Coriolisovej sily v tomto prípade nebol určujúci, ked’že vodné toky na Podunajskej nížine mali tendenciu presúvat' svoje korytá rôznymi smermi, zohl'adňujúc spomínané faktory (primárne tektoniku), napr. spomínaná avulzia Malého Dunaja smerom ku Kolárovu sa udiala presne opačným smerom, ako nami študované avulzie. Avulzie na dolnom úseku dolného Váhu v smere na západ, teda opačným smerom, ako je tomu na Trnavskej pahorkatine, boli spôsobené, zdá sa, intenzívnejším poklesávaním územia v okolí Komárna a Kolárova.

S tvorbou depresie v okolí Kolárova súvisí aj staršia zmena toku Váhu prechádzajúceho z Podunajskej pahorkatiny na Podunajskú rovinu na juhovýchodný (Vaškovský 1977). Na poklesávajúci charakter tohto úseku poukazuje aj pôdorysná vzorka Váhu (pred regulačnými zásahmi). Na obrázku 5 si môžeme všimnút', že Váh v úseku približne medzi Nededom a Kameničnou (v okolí Kolárova) vytváral mimoriadny počet meandrov, čo je spôsob, akým sa rieka prispôsobuje poklesávaniu v tomto priestore. Podobným spôsobom sa prispôsoboval 
lokálnym tektonickým podmienkam aj v priestore medzi Sered’ou a Šal'ou (Procházka a Pišút 2015). V starších prácach sa objavuje názor, že istý vplyv na prevládajúci juhovýchodný smer Váhu na Podunajskej rovine mohol mat' Dunaj, ktorého agradačný val odtláča Váh (Dlabač 1960). Na tomto úseku sa spomínajú nápadné ohyby koryta (obr. 5), ktoré majú poukazovat' na tektonicky podmienené snahy Váhu presúvat' koryto v neskoršom období práve juhozápadným smerom, a to napriek vplyvu odtláčania Dunajom (Lukniš 1969).

\section{Záver}

V predkladanom príspevku oboznamujeme s výsledkami štúdia zaniknutých významnejších bočných ramien Váhu na Podunajskej nížine. Zaoberali sme sa priebehom ich tokov v historických dobách (ich vek nie je numericky datovaný) a dôkazom, že niektoré z nich plnili funkciu hlavného koryta Váhu. Spoločným menovatel'om týchto bočných ramien je skutočnost', že vznikali mechanizmom avulzií prvého rádu zrejme počas významnejších povodní. Viacnásobné avulzie boli podmienené tiltingom Trnavskej pahorkatiny na východ, resp. kaptáciou poklesávajúcich paniev v okolí Kolárova a Komárna. Vznik týchto ramien nie je absolútne datovaný pre jednotlivé povodne, na ich genézu však poukazujú polohové vzt’ahy. Opis ramien teda poukazuje na mimoriadnu dynamiku dolného Váhu počas malej doby l'adovej, ktorá sa prejavovala aj mechanizmom avulzií (ich zvýšeným počtom). Zdá sa, že tento plnil významnejšiu úlohu aj pri formovaní riečnej siete na celej Podunajskej nížine, t. j. vrátane Podunajskej roviny, než sa doteraz predpokladalo. Avulzie prvého rádu boli teda popri laterálnej erózii, ktorá mala za ciel' rozvoj riečnych meandrov, taktiež určujúcim mechanizmom v zmenách riečneho systému dolného Váhu. K avulziám prvého rádu v súvislosti s laterálnym obmedzovaním toku, resp. zužovaním aktívnej nivy výstavbou protipovodňových hrádzí, dochádzalo čoraz menej, resp. vznikali len kratšie avulzné ramená (stovky metrov až niekol'ko málo kilometrov). Protipovodňové hrádze sa budovali najskôr v zázemí obcí a miest. Súvislejšie, dlhšie úseky potom skôr na Podunajskej rovine, kde bol spomalený povrchový odtok, a až neskôr (v 19. storočí) na vyšších úsekoch. V 18. a 19. storočí preto význam avulzií najmä na Podunajskej rovine klesal a rozhodujúcim mechanizmom transformácie riečneho systému bola laterálna aktivita koryta tvorbou a rozvojom meandrových oblúkov.

Jedným z najväčších prínosov práce je opis koryta Lodná cesta, ktoré je doposial' z vedeckej literatúry takmer neznáme. Je pravdepodobné, že rameno Hajó Út mohlo byt' aktívne a plnit' funkciu hlavného koryta Váhu ešte v 13. - 14. storočí. V 15. storočí prebehla avulzia na Váhu, vd’aka ktorej bolo postupne koryto Hajó Út opustené a funkciu hlavného koryta prebralo novovzniknuté avulzné koryto, ktoré tieklo bezprostredne na západ pozdíž agradačného valu Hajó Út. Pri miléniovej povodni v roku 1501 došlo $\mathrm{k}$ avulzii Malého Dunaja v úseku medzi Topol’níkmi a Kolárovom, čo malo za následok (kvôli zvýšeným prietokom) aj zvýšenie aktivity koryta na úseku Vážskeho Dunaja. Pred rokom 1581 dochádza k avulzii koryta Vad Ástvany a d’alších paralelných korýt, ktoré čiastočne zotreli pôvodné koryto Lodná cesta. Poslednou významnou hydrografickou zmenou v tomto regióne, súvisiacou aj s vyššie opísaným systémom, bolo odstavenie Starej Žitavy, a to niekedy pred rokom 1670.

Dôležitým zistením je aj skutočnost', že viaceré generácie hlavného koryta Váhu na území Martovskej mokrade poukazujú na tektonicky podmienenú tendenciu Váhu v tomto priestore prekladat' koryto v smere na juhozápad, teda v opačnom smere, ako je dobre známa tendencia presunu Váhu smerom na východ na Podunajskej pahorkatine.

$\mathrm{K}$ d’alšiemu upresneniu vývoja riečnej siete $\mathrm{v}$ tomto regióne by mohli napomôct' štúdie zamerané na využitie iných metodických nástrojov, napr. analýzu lidarového modelu reliéfu, či existujúcej geologickej vrtnej dokumentácie. 


\section{Zoznam použitých máp}

1. Mappa Fluvii Vaag inter Op. Püstény et Possessionem Moravanka repraesentans. 1770. Rozmery 37,5 x 48,5 cm. Mad'arský národný archív sign. S 12 - Div. XI. - No. 4:5.

2. Warhafftige Situation aller Städt u. Vestungen, So' von der Käyserl. Residenz Stadt Wien bis an die Essecke Brücken, so wol an der Donau als ander Flüssen, theils noch in der Türcken Gewalt sich befinden, theils aber von den Christen eine zeithero erobert worden. 1670, Johann Hoffmann. Mierka 1:960000, rozmery 55 x $39 \mathrm{~cm}$. Inštitút a múzeum vojenskej histórie sign. B IX a 482/7.

3. Particular Land Cart der beiden grose kleine Insel Schüt. 1670, Szántai L., Szathmáry T. Mierka 1:150000, rozmery 33,9 x 59,6 cm. Szechényiho národná knižnica, sign. TK3026.

\section{Literatúra}

ALAPY, Gy. 1994: A csallóközi halászat története. Bratislava (Kalligram).

BALON, E. K. 1967: Vývoj ichtyofauny Dunaja, jej súčasný stav a pokus o prognózu d’alších zmien po výstavbe vodných diel. Biologické práce $S A V, 13,5-121$.

CEPRLK 2015: Historická ortofotomapa Slovenska, stav v roku 2010. Zvolen (Technická univerzita vo Zvolen). Dostupné online: http://mapy.tuzvo.sk/HOFM. (CEPRLK - Centrum excelentosti pre podporu rozhodovania $v$ lese a krajine).

DLABAČ, M. 1960: Poznámky ke vztahu mezi tvarem povrchu a geologickou stavbou Podunajské nížiny. Geologické práce, 59(7), 69-100.

HLADKÝ, J. 2011: Hydronymia povodia Dudváhu. Trnava (Trnavská univerzita v Trnave, Pedagogická fakulta).

HLADKÝ, J. 2012: Zo starej hydronymie stredného Podudvažia. In Ološtiak, M. ed. Jednotlivé a všeobecné v onomastike. Prešov (Prešovská univerzita v Prešove), 202-209.

HLADKÝ, J., ZÁVODNÝ, A. 2015: Hydronymia Žitného ostrova. Trnava (Typi Universitatis Tyrnaviensis).

HOLBROOK, J., SCHUMM, S. A. 1999: Geomorphic and sedimentary response of rivers to tectonic deformatrion: a brief review and critique of a tool for recognizing subtle epeirogenic deformation in modern and ancient settings. Tectonophysics, 305, 287-306. DOI: https://doi.org/10.1016/S0040-1951(99)00011-6.

HOLČ́IK, J., HENSEL, K. 1971: Ichtyologická príručka. Bratislava (Obzor).

IŠTOK, P., IŽOF, J. 1990: Podmienky vzniku a vývoja osídlenia krajiny dolného toku Váhu vo svetle geografických a archeologických prieskumov. Študijné zvesti Archeologického ústavu $S A V, 26(1), 145-168$.

JANKÓ, A., OROSS, A., TIMÁR, G. 2005: A második katonai felmérés 1819-1869 [Druhé vojenské mapovanie]. DVD. Budapest (HM Hadtörténeti Intézet és Múzeum Térképtára; Arcanum Adatbázis Kft.).

KOLEČÁNI, K. 1998: Palárikovo 1248 - 1998. Komárno (KT).

LEHOTSKÝ, M., KIDOVÁ, A., RUSNÁK, M. 2015: Slovensko-anglické názvoslovie morfológie vodných tokov. Geomorphologia Slovaca et Bohemica, 15(1), 5-62.

LUKNIŠ 1969: Poznámky k vývinu reliéfu Podunajskej nížiny v okolí Nových Zámkov. Studia Geographica, 1(1), 45-51.

LUKNIŠ, M., BUČKO, Š. 1953: Geomorfologické pomery Podunajskej nížiny v oblasti medzi Novými Zámkami a Komárnom. Geografický časopis, 5(3-4), 131-168.

MACHÁČEK, P. 1935: Šal'a v dejinách. Nové Zámky (Winter).

MANÁK, M. ed. 2010: Drahovce...dejiny obce. Čadca (Magma).

MASLÍKOVÁ, L'. 2010: Vývoj osídlenia dolného Ponitria do polovice 14. storočia. Historia Nova, 1(2), 8-31.

MEDŇANSKÝ, A. 2007: Malebná cesta dolu Váhom. - 4. vyd. Bratislava (Vydavatel'stvo Spolku slovenských spisovatel'ov).

MOL 2006: A Duna-mappáció: A Duna folyó magyarországi szakaszának térképei (18191833) az osztrák határtól Péterváradig [Dunajské mapovanie]. DVD. Pécs (Médiatér Kft.). (MOL - Magyar Országos Levéltár). 
NOVOTNÝ, J., CEBECAUEROVÁ, M. 2016: Vybrané aspekty transformácie fluviálneho systému rieky Váh v 20. storočí. Geografický časopis, 68(1), 73-92.

OBEC NESVADY 2018: Heraldika. Dostupné online: https://www.nesvady.sk/o-obci/ zakladne-info/heraldika/.

OK 2018: Urbaria et conscriptiones. Dostupné online: https://archives.hungari cana.hu/ en/urbarium/. Budapest (OK - Országgyülési Könyvtár; Arcanum Adatbázis Ltd).

PETROVSZKI, J., SZEKÉLY, B., TIMÁR, G. 2012: A systematic overview of the coincidences of river sinuosity changes and tectonically active structures in the Pannonian Basin. Global and Planetary Change, 98-99(1), 109-121. DOI: https://doi.org/10.1016/ j.gloplacha.2012.08.005.

PIERIK, H. J., STOUTHAMER, E., SCHURING, T., COHEN, K. M. 2018: Human-caused avulsion in the Rhine-Meuse delta before historic embankment (The Netherlands). Geology, 46, 935-938. DOI: https://doi.org/10.1130/G45188.1.

PIŠÚT, P. 1997: Starobylé toponymá na Podunajskej nížine a historický výskum riečisk. Geographia Slovaca, 12, 119-130.

PIŠÚT, P., BŘÍZOVÁ, E., ČEJKA, T., PIPÍK, R. 2010: Paleofloristic and paleofaunistic analysis of Dudváh River oxbow and implication for Late Holocene paleoenvironmental development of the Žitný ostrov Island (SW Slovakia). Geologica Carpathica, 61, 513-533. DOI: https://doi.org/10.2478/v10096-010-0032-1.

PIŠÚT, P., PROCHÁZKA, J., MATEČNÝ, I., BANDURA, P. 2016: Vývoj koryta Váhu pri Leopoldove v 17. - 20. storoči a odozva rieky na zásahy človeka. Bratislava (Univerzita Komenského).

PROCHÁZKA, J., PIŠÚT, P. 2015: Regulácie koryta nížinného meandrujúceho vodného toku v období r. 1782 - 1900 (na príklade rieky Váh v úseku Sered’ - Komárno). Geographia Cassoviensis, 9, 44-55.

PROCHÁZKA, J. 2017: Geomorfologická odozva environmentálnych zmien riečneho koryta dolného Váhu. Dizertačná práca. Bratislava (PriF UK).

PÜSPÖKY NAGY, P. 2001: Erb a symboly obce Nesvady: základná dokumentácia. Bratislava (Péter Püspöki Nagy).

SEDLÁK, V. 2000: Historicko-geografické podmienky tvorby sídlisk medzi Malým Dunajom a Váhom. Historický zborník, 10, 31-39.

ŠMILAUER, V. 1932: Vodopis starého Slovenska. Práce učené společnosti Šafaříkovy v Bratislavě, 9.

TIMÁR, G., SÜMEGI, P., HORVÁTH, F. 2005: Late Quaternary dynamics of the Tisza River: Evidence of climatic and tectonic controls. Tectonophysics, 410, 97-110. DOI: https://doi.org/ 10.1016/j.tecto.2005.06.010.

VAŠKOVSKÝ, I. 1977: Kvartér Slovenska. Bratislava (Geologický ústav Dionýza Štúra).

Táto práca bola riešená v rámci grantov VEGA 1/0781/17 Riečne alúviá ako archívy prírody a l'udskej civilizácie a APVV-15-0054 Fyzikálne založená segmentácia georeliéfu a jej geovedné aplikácie.

\section{Adresa autora}

Mgr. Juraj Procházka, Ph.D.

Univerzita Komenského v Bratislave

Prírodovedecká fakulta

Katedra fyzickej geografie a geoekológie

Ilkovičova 6, 84215 Bratislava

Slovensko

juraj.prochazka@uniba.sk 